\title{
NOTAS
}

\section{Reflexiones sobre un manual clásico de la Filología Española: Morfología histórica del español de M. Alvar y B. Pottier}

\author{
Ana Isabel Navarro CARrasco \\ (Universidad de Alicante)
}

No creemos que sea tarde - porque en estos casos nunca lo es- para poner de relieve una obra como la que tenemos ante nuestros ojos (Gredos, Madrid, 1983, 533 págs.). No obstante, esperamos que el lector con su beneplácito justifique estas líneas que debieron salir en su momento y que, entonces, se perdieron por el camino.

Estamos en presencia de uno de esos libros que constituyen un hito en la historia lingüística; un trabajo inexistente en español; una obra que se echaba en falta y a la que estamos ya tan habituados que no podríamos prescindir de ella; un libro que, por sus planteamientos, las muchas fuentes utilizadas, la información proporcionada y el rigor científico, se ha convertido — desde su nacimiento- en un trabajo cumbre de nuestra lingüística. Morfología histórica del español junto con el Manual de gramática histórica de Menéndez Pidal y la Historia de la lengua española de Lapesa son los tres manuales claves para los alumnos de Gramática Histórica y de Historia del español. Son la base para todo estudio diacrónico del español.

Como sus mismos autores exponen en el prólogo, esta obra estaba proyectada, allá por los años sesenta, para formar parte de la Enciclopedia Lingüística 
Hispánica. Ahora Alvar y Pottier llegan felizmente a buen puerto con este trabajo tan deseado por todos: la morfología histórica de la lengua española.

El libro consta de dieciocho capítulos y tres índices (temático, de palabras y de nombres propios). En el capítulo I se nos habla de las palabras con lexema, sin lexema y de los tipos de lexemas (primarios, secundarios y con distancia morfológica). En el II de la morfología independiente y dependiente, del plano paradigmático y del sintagmático, y de la morfología latente. En el III de las clases de morfemas y de los lexemas nominales. En el IV del morfema de género y número. En el $\mathrm{V}$ de las transformaciones que sufren las declinaciones latinas: el acusativo sustituyó a los diversos casos; restos que han quedado de los casos latinos en español; la reducción de las declinaciones, y, finalmente, la reestructuración. El VI se dedica al adjetivo: comparativo, superlativo, numerales, distributivos y multiplicativos. El VII a los posesivos, demostrativos y a la aparición del artículo como debilitamiento de los demostrativos. El VIII a los pronombres personales, relativos, interrogativos e indefinidos. Los capítulos IX, X, XI y XII al verbo. Aparece, entre otras cuestiones, una lista del origen de los verbos en -ar en español ( $\$ \S 124.1$ - 124.4); las desinencias de persona y número; el presente, el imperfecto, el futuro y el perfecto. El capítulo XIII se ciñe a las preposiciones sistematizándolas, de tal manera que las preposiciones latinas se ordenan en tres sistemas: las «que indican movimiento hacia o desde un límite de referencia», las «que se refieren a un límite doble, o sea una interioridad» y las «que suponen un límite orientado (no sistemático)» ( $\S \S 180.1-205)$. El XIV está dedicado a las conjunciones coordinadas, comparativas, a las partículas deícticas y a una serie de elementos positivos y negativos, modales y apreciativos. Hay un capítulo sobre prefijación (cap. XV), enumerando y explicando todos los prefijos latinos y atendiendo a los griegos. Dos capítulos para la sufijación (caps. XVI y XVII), señalándose, por un lado, los sufijos diminutivos y aumentativos, $y$ explicitándose, por otro, los sufijos que sirven para crear sustantivos a partir de un sustantivo, de un adjetivo y de un verbo. Igualmente, hay adjetivos que se forman a partir de un adjetivo + sufijo, o bien sustantivo + sufijo, o verbo + sufijo. Lo mismo sucede con el verbo. Finalmente, las últimas páginas del libro están dedicadas a la composición (cap. XVIII).

La bibliografía que manejan los autores, por todas partes que se mire, es exhaustiva. Ahí podemos acudir en busca de material bibliográfico sobre muchos temas variados. Por citar algunos ejemplos señalaremos que en la nota 40 a la pág. 128 se da extensa bibliografía sobre laísmo, leísmo y loísmo; en la nota 6 a la pág. 364, un amplísimo material sobre el diminutivo; en la nota 77 a la pág. 378 sobre el superlativo; en la nota 79 a la pág. 379 sobre los interfijos, etc. Esto en cuanto a lo que se refiere a información bibliográfica que puede servirnos de ayuda para iniciar un trabajo, pero lo más importante de todo es la gran cantidad de obras — tanto en lo antiguo como en lo moderno- que los autores manejan y 
de las que extraen datos y conclusiones. No hay ni un solo estudio dialectal, de los que contamos en las hablas y dialectos peninsulares, que no se haya tenido en cuenta y del que no se haya sacado un dato aprovechable, de ahí el abanico de posibilidades que se ofrece para una cuestión concreta, mostrándose el resultado en dialectos históricos, en hablas vivas, en el español actual, etc.

Pero no solamente se ha atendido a las variedades lingüísticas peninsulares sino que se ofrece también importantísima documentación sobre el español de América.

Conclusiones de gran interés son las obtenidas de los atlas lingüísticos españoles: $A L E A, A L E I C a n, A L E A N R, A L P I$. De esta manera, los materiales que se manejan son abundantísimos, porque los atlas ofrecen una documentación amplísima no tenida en cuenta en la gran mayoría de los estudios actuales, los cuales se enriquecerían si los utilizaran.

Morfología histórica del español es una obra donde el acopio de material allegado y la reelaboración que se ha hecho del mismo permite ofrecer un trabajo bien documentado, rico y valioso.

A pesar de ser dos personas las que intervienen en la elaboración de este trabajo, en ningún momento se siente desvinculación entre lo que ha hecho uno y lo que ha hecho otro, porque no se acierta a discernir dónde comienza y termina la mano de cada investigador, lo cual se debe, principalmente, a la estrecha colaboración que ha existido entre ambos autores, a la solidez de sus planteamientos y a las revisiones que se han hecho de todo el libro.

Estamos, pues, como decíamos al principio, ante una obra clave de la linguística española, una obra que debe tenerse en cuenta para muy diversas investigaciones dentro de nuestro campo y que constituye un trabajo clásico dentro de los trabajo clásicos a los que nos tienen acostumbrados Alvar y Pottier. Es una obra de madurez. Es un libro realizado con la sabiduría que da el trabajo bien hecho y diario a lo largo de toda una vida. Es la obra de dos grandes maestros sabios de nuestra filología: Manuel Alvar y Bernard Pottier. 